\title{
Potential use of phosphogypsum in paving blocks
}

\section{Abdessattar Hamdi}

PhD student, Laboratory of Civil Engineering, National Engineers School of Tunis, University of Tunis El Manar, Tunis, Tunisia (Orcid:0000-0001-89824118) (corresponding author: hamdi.abdessattar@enit.utm.tn)

\author{
Nejib Ben Jamaa \\ Professor, Département de Génie Civil, École Nationale d'Ingénieurs de \\ Gabès, Université de Gabès, Gabès, Tunisia (Orcid:0000-0001-6328-5929) \\ Imen Kallel Kammoun \\ Professor, Département de Génie Civil, École Nationale d'Ingénieurs de \\ Sfax, Université de Sfax, Sfax, Tunisia (Orcid:0000-0001-8523-4241)
}

The present work aims to contribute to finding more recycling routes for phosphogypsum (PG) and its potential uptake in the material construction industry as paving blocks. Laboratory testing was conducted to formulate mixes using PG as fine sand replacement. An optimal $20 \%$ substitution rate was proved. Industrially processed paving blocks were made for high-quality experimental investigation. The most interesting testing results of PG paving blocks are the low water absorption coefficient of $5.7 \%$ and excellent mechanical properties, including high compressive and flexural strengths at early age (20.7 and $4.65 \mathrm{MPa}$ at 7 days, respectively). Compressive strength evolves with respect to the curing period: $26 \%$ increase at 28 days and $36 \%$ increase at 90 days; flexural strength evolves from $6 \%$ at 28 days to $10 \%$ at 90 days. The leaching test showed low levels of heavy metals released, and their concentrations were lower in the mix than in the raw PG. For all the aforementioned results, PG waste from a phosphate plant in Gabès, Tunisia was proved to have high potential for reuse in the manufacturing of paving blocks with low health risks and excellent properties. Reusing PG waste in paving blocks would thus contribute to solving an environmental issue and reduce the use of sand, which is prone to depletion as a non-renewable resource.

\section{Notation \\ $F_{\mathrm{c}} \quad$ breaking load (N) \\ $F_{\mathrm{f}} \quad$ breaking load at the middle of the prism (N) \\ $l \quad$ distance between the supports ( $\mathrm{mm})$

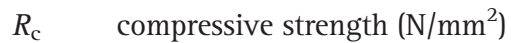 \\ $R_{\mathrm{f}} \quad$ flexural strength $\left(\mathrm{N} / \mathrm{mm}^{2}\right)$}

\section{Introduction}

The phosphoric acid $\left(\mathrm{P}_{2} \mathrm{O}_{5}\right)$ industry is responsible for releasing huge amounts of phosphogypsum (PG). Phosphoric acid, widely used in fertilizer, pharmaceutical and detergent industries and for other uses, is obtained by a wet process of transforming natural phosphate ore using sulfuric acid at $70-80^{\circ} \mathrm{C}$ following the chemical reaction ${ }^{1}$

$$
\begin{gathered}
\mathrm{Ca}_{10}\left(\mathrm{PO}_{4}\right)_{6} \mathrm{~F}_{2}+10 \mathrm{H}_{2} \mathrm{SO}_{4}+20 \mathrm{H}_{2} \mathrm{O} \\
\text { I. } \quad \rightarrow 6 \mathrm{H}_{3} \mathrm{PO}_{4}+10 \mathrm{CaSO}_{4} \cdot 2 \mathrm{H}_{2} \mathrm{O}+2 \mathrm{HF}
\end{gathered}
$$

The global demand for phosphoric acid is rapidly growing. It was projected to reach $45.9 \mathrm{Mt}$ in $2018,{ }^{2}$ leading to disposal of $230 \mathrm{Mt}$ of PG in tailings or by direct discharge into seas and watercourses.

In Tunisia, the phosphate industry is a pillar of the economy. Tunisian phosphate ore mines are located in south-western Tunisia, while for trading purposes, the transformations and processing take place in two main plants located in coastal sites (the cities of Gabès and Sfax). According to recent oceanographic surveys, ${ }^{3}$ the Gulf of Gabès ecosystem and biodiversity are severely altered because of massive discharge of PG waste. With current PG disposal rates, the degradation of marine ecosystems at the Gulf of Gabès has become a serious environmental issue at both the regional and national scale. Hence, measures to attenuate the environmental impacts of PG disposal should be undertaken to save the Gulf of Gabès. Studies were conducted to justify the reuse and recycling of PG in Tunisia and worldwide in applications mostly in civil engineering and farming (as fertilizers). Unfortunately, these applications all together absorb only $15 \%$ of the discharged PG at the global scale. At the local scale, the situation is more critical: the recovery rate of $\mathrm{PG}$ waste is under $8 \%$.

PG waste reuse applications found in the recent literature include use as a fertilizer in agriculture and in the construction industry and cement production. Indeed, previous research findings proved PG waste may be used in the building material industry, ${ }^{4}$ in soil amendment applications, ${ }^{5}$ Portland cement production ${ }^{6}$ and in road construction. ${ }^{7}$

The underlying health issues ${ }^{3}$ due to $\mathrm{PG}$ radioactivity may explain the relatively conservative reuse of PG in applications where direct human use (farming) and/or extended exposure (construction material in building) is expected.

New applications where PG reuse risk to human health is lower are therefore needed. The main idea of this investigation is to manufacture a fully engineered product for which exposure during use should be short and/or intermittent; open-area and outdoor use would reduce radioactivity whatever the levels are. Interlocking concrete paving blocks have gained the authors' attention as a promising alternative for PG valorization, particularly since no prior effort has been devoted to conducting research about such products. Paving blocks available on the market are made of conventional cement mortar (Portland cement, fine sand and crushed stone 
aggregate). In the present approach, fine sand will be partially substituted by an optimal PG rate to be determined. Optimality will be reached by appropriate mix proportioning to provide acceptable water absorption and mechanical strengths. As far as the authors know, no previous research has investigated PG reuse in making paving blocks. Nevertheless, standard testing protocols largely followed in similar reuse applications were adopted.

The experimental investigation conducted herein aims to provide research results for fully engineered paving blocks that meet the intended use requirements: sound physical/mechanical properties, radioactivity below allowable thresholds, durability and capability to afford efficient solutions to the aforementioned environmental issues.

\section{Materials and methods}

The mix design of the paving blocks using PG waste in partial substitution of fine sand was performed at laboratory conditions (LPGPB) to identify the optimum LPGPB design mix with respect to PG-substitution rates (from 10 to $60 \%$ ). A PGsubstitution rate of $20 \%$ was retained and was used to make paving blocks at factory conditions (FPGPB). In the following section, the identification of raw materials and the manufacturing method of paving block samples are detailed

\subsection{Materials}

\subsubsection{Characteristics of phosphogypsum}

The PG samples used in preparing paving blocks were obtained by oven-drying the PG sludge collected at the outlet of a phosphoric acid factory at Gabès City in the south-east of Tunisia (Figure 1) at a temperature below $40^{\circ} \mathrm{C}$.
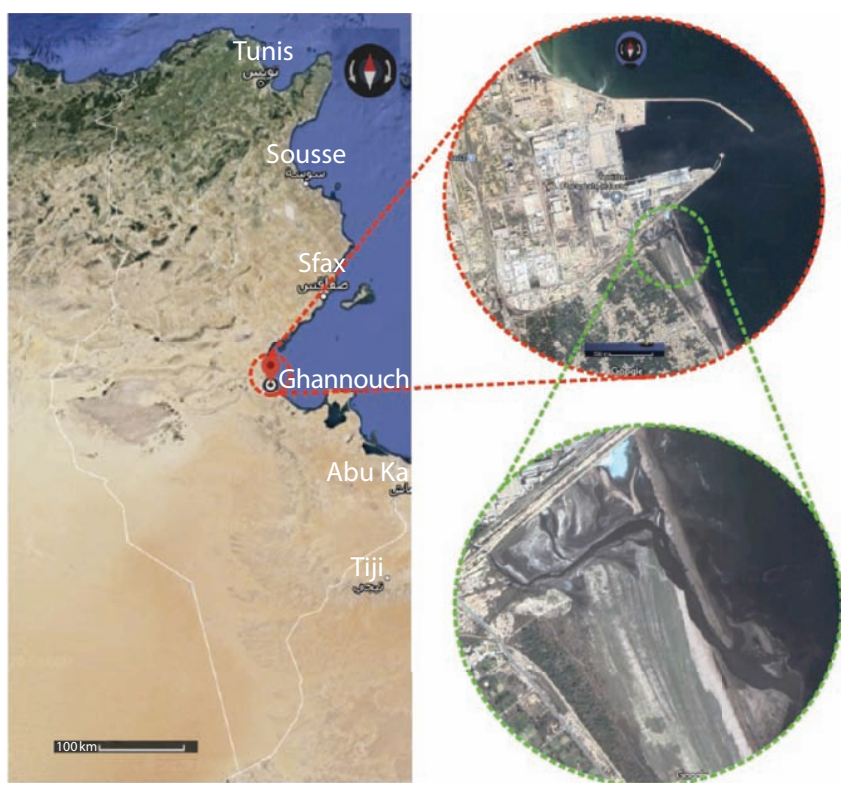

Figure 1. Geographical situation of the Tunisian Chemical Group in the Gulf of Gabès and disposal of PG in the sea (Satellite images from Google Maps(C)
The PG characteristic granularity, plasticity, grain density and radioactivity were identified.

\subsubsection{Granularity}

The PG particle size distribution (PSD) was obtained by laser diffraction analysis (LDA) using a Malvern Mastersizer 2000 laser granulometer, which uses a wet method by dispersing the particles in water. The measurement range chosen was between 0.01 and $2000 \mu \mathrm{m}$.

Results of LDA (Figure 2) and visual inspection (Figure 3) show a fine sand-like granulometry $(90 \%$ fines portion lower than $250 \mu \mathrm{m})$. This result is in line with the above approach.

\subsubsection{GRAIN DENSITY}

The PG grain density was determined using the pycnometer method. The measured density of $2.31 \mathrm{~g} / \mathrm{cm}^{3}$ is comparable with that of natural gypsum $\left(2.32 \mathrm{~g} / \mathrm{cm}^{3}\right)$. Later, the authors will show that effectively, gypsum is prevalent in PG chemical composition. The PG particle density fluctuated from 2.27 to $2.4 \mathrm{~g} / \mathrm{cm}^{3}{ }^{3}$. The differences may be explained by the presence of impurities. Tunisian PG presents a relatively low level of impurities.

\subsubsection{PLASTICITY}

The Atterberg limits (plasticity and liquidity) were determined according to the standard ASTM D 3282. ${ }^{9}$ The liquidity limit is $63 \%$; the plasticity limit is $40 \%$. PG plasticity calculated index is $23 \%$. According to the aforementioned norm, PG is very plastic.

\subsubsection{CHEMICAL COMPOSITION}

A Hitachi S2500 scanning electron microscope (SEM) was used to examine the PG crystalline form as shown in Figure 4. The PG sample has a crystalline form with tabular crystals of length ranging between 20 and $200 \mu \mathrm{m}$ and with an average length of $50 \mu \mathrm{m}$. Other metal traces revealed by SEM analysis need further chemical identification.

The chemical analysis was performed by X-ray fluorescence, which consists of exciting the sample using an X-ray tube or radioelements

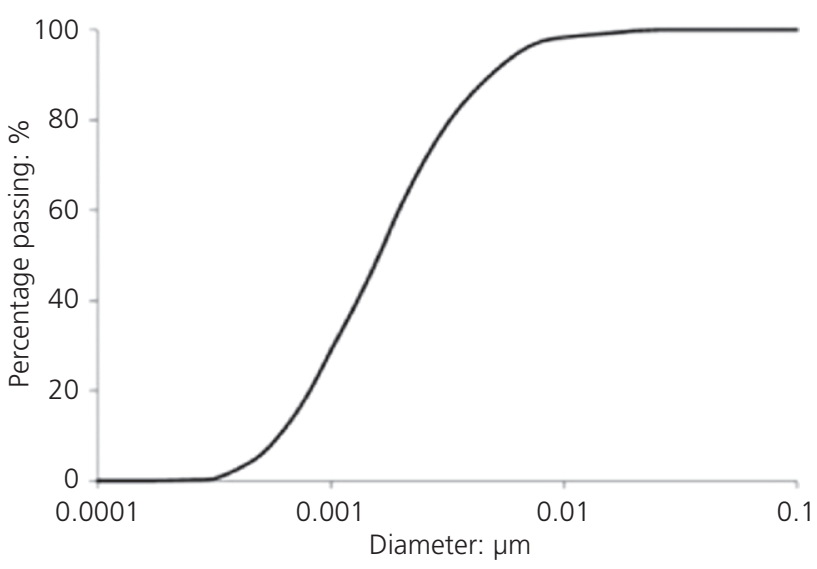

Figure 2. Granulometric curve of the studied Tunisian PG 


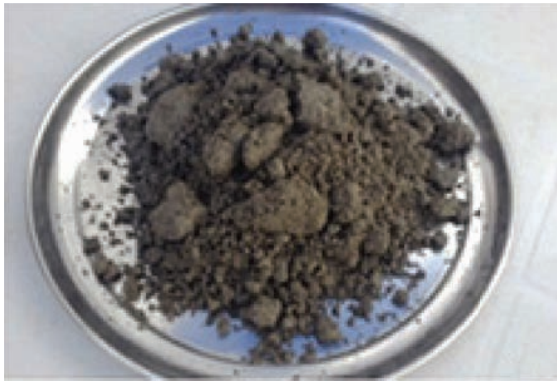

(a)

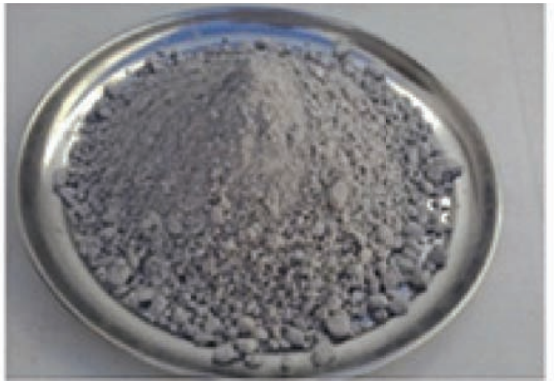

(b)

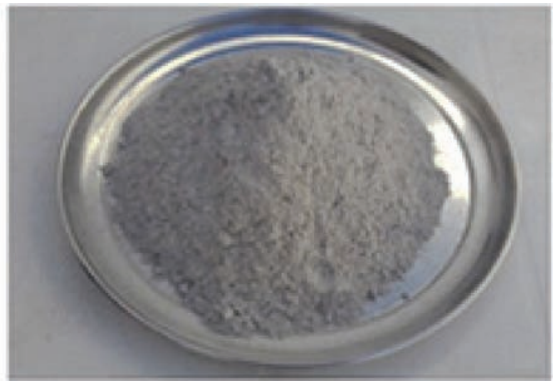

(c)

Figure 3. Visual aspects of PG: (a) PG sludge at the discharge outlet filter; (b) oven-dried PG at $105^{\circ} \mathrm{C}$; (c) crumbled PG sample

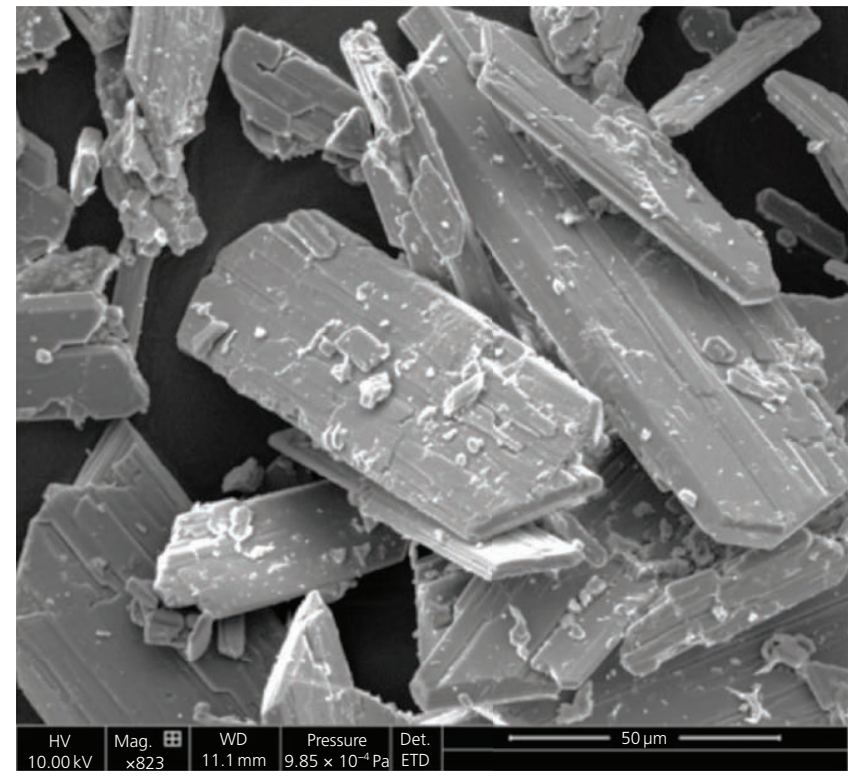

Figure 4. SEM micrograph of the PG

and analyzing the spectrum (in the wavelength or energy) of the emitted X-rays. The laboratory results show that PG contains mainly lime (calcium oxide $(\mathrm{CaO})$ ), silica (silicon dioxide $\left(\mathrm{SiO}_{2}\right)$ ) and in particular sulfur (sulfur trioxide $\left(\mathrm{SO}_{3}\right)$ ). Other elements are available in traces, such as aluminum oxide $\left(\mathrm{Al}_{2} \mathrm{O}_{3}\right)$, sodium oxide $\left(\mathrm{Na}_{2} \mathrm{O}\right)$, phosphoric acid, titanium dioxide $\left(\mathrm{TiO}_{2}\right)$ and strontium oxide $(\mathrm{SrO})$; the chemical composition and the loss on ignition (LOI) are given in Table 1.

X-ray diffraction (XRD) was used to identify the mineralogical phases. The apparatus used was a Panalytical X'Pert Pro diffractometer piloted by the X'Pert Data Collector software, which provides data acquisition, and X'Pert HighScore, which ensures data processing and phase identification. The result of this characterization is presented in
Figure 5. It shows a predominant presence of gypsum (86.15\%) and, to a lesser extent, of calcite $(10.76 \%)$ and quartz $(3.07 \%)$.

Infrared spectrum analysis was used to detect the PG main components by identifying their respective vibration modes. Figure 6 shows the PG vibration wavelengths ranging from 500 to $4000 \mathrm{~cm}^{-1}$. The different vibration bands associated with PG are provided.

- The vibration wavelengths at 604 and $670 \mathrm{~cm}^{-1}$, associated with the $v_{4}$ sulfate $\left(\mathrm{SO}_{4}\right)$ ion vibration, are very sharp and very strong.

- The wavelength vibration at $1164 \mathrm{~cm}^{-1}$, which is associated with $v_{3}$ sulfate $\left(\mathrm{SO}_{4}\right)$, is very marked and very important.

- Vibration bands of water appear at 1624 and $1690 \mathrm{~cm}^{-1}$ for $v_{2}$ water $\left(\mathrm{H}_{2} \mathrm{O}\right)$.

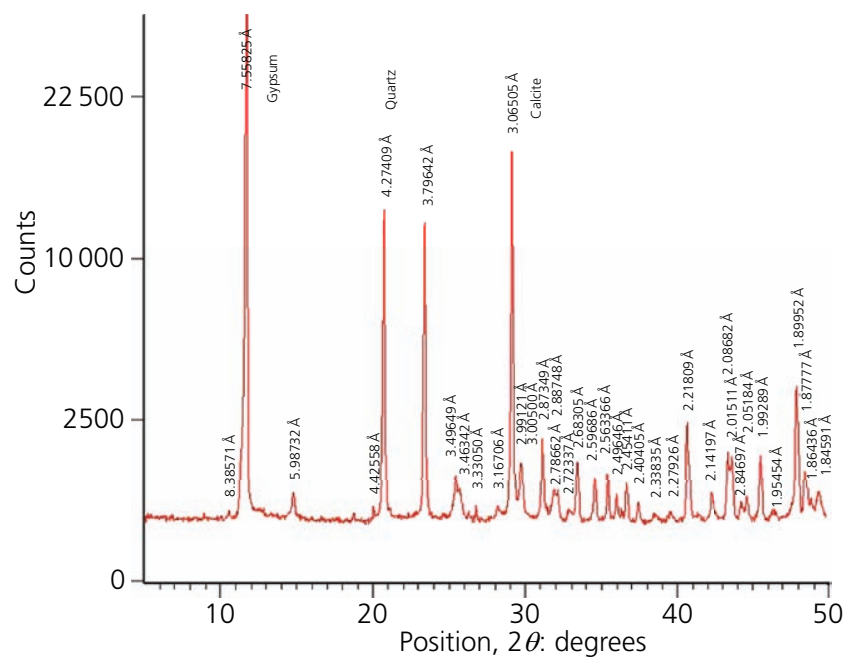

Figure 5. XRD patterns of the studied PG

Table 1. Chemical composition of PG in weight $\%$

\begin{tabular}{|lccccccccc}
$\begin{array}{l}\text { Calcium } \\
\text { oxide }\end{array}$ & $\begin{array}{c}\text { Silicon } \\
\text { dioxide }\end{array}$ & $\begin{array}{c}\text { Aluminum } \\
\text { oxide }\end{array}$ & $\begin{array}{c}\text { Sodium } \\
\text { oxide }\end{array}$ & $\begin{array}{c}\text { Potassium } \\
\text { oxide }\end{array}$ & $\begin{array}{c}\text { Sulfur } \\
\text { trioxide }\end{array}$ & $\begin{array}{c}\text { Phosphoric } \\
\text { acid }\end{array}$ & $\begin{array}{c}\text { Titanium } \\
\text { dioxide }\end{array}$ & $\begin{array}{c}\text { Strontium } \\
\text { oxide }\end{array}$ & $\begin{array}{l}\text { LOI } \\
\text { oxide }\end{array}$ \\
\hline 38.26 & 2.03 & 0.07 & 0.86 & 0.09 & 42.89 & 2.21 & 0.03 & 0.22 & 14.91 \\
\hline
\end{tabular}




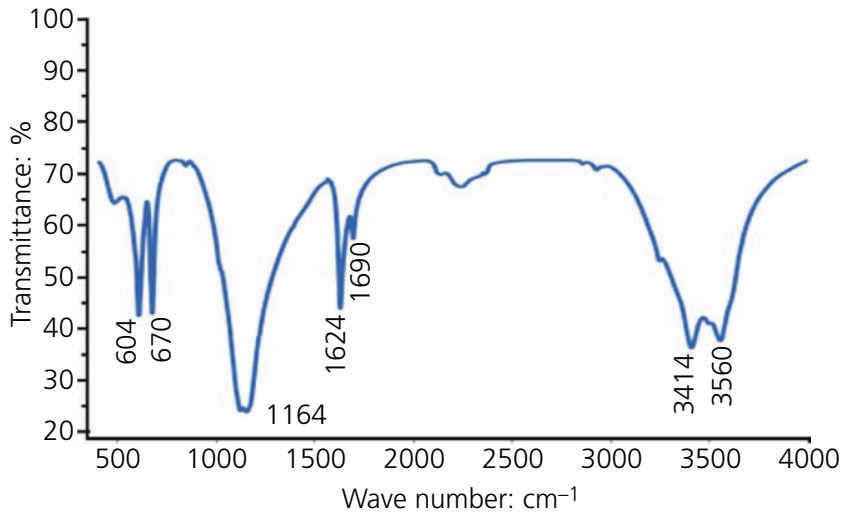

Figure 6. Infrared spectra of PG

- The band at $1624 \mathrm{~cm}^{-1}$ is quite marked, the one at $1690 \mathrm{~cm}^{-1}$ is weaker and the bands at 3414 and $3560 \mathrm{~cm}^{-1}$ are those of $v_{1}$ water $\left(\mathrm{H}_{2} \mathrm{O}\right)$.

\subsubsection{WATER CONTENT}

The water content of the PG (at the sludge state before drying) is $35 \%$. This result justifies the need for drying to control the mix proportioning.

\subsubsection{RADIOACTIVITY}

The natural decomposition of uranium present in the phosphate ore causes an increase of the radium content, leading to the radioactivity of the PG. Analyses were performed with a broad-energy germanium detector (Canberra), with a relative efficiency of $43 \%$. Standard geometry samples were prepared with a standard radionuclide solution (QCYA17840, Eckert \& Ziegler Nuclitec GmbH) to calibrate the geometry of the measured samples and the detector efficiency. Uranium-238 $\left({ }^{238} \mathrm{U}\right)$ activity was determined using four gamma peaks of bismuth-214 $\left({ }^{214} \mathrm{Bi}\right)$ and two peaks of lead-214 $\left({ }^{214} \mathrm{~Pb}\right)$ and radon-222 $\left({ }^{222} \mathrm{Rn}\right)$ after an ingrowth period in a sealed container. Uranium-235 $\left({ }^{235} \mathrm{U}\right)$ was determined using the photopeak at $143 \mathrm{keV}$, and thorium-232 $\left({ }^{232} \mathrm{Th}\right)$ was determined by the $911 \mathrm{keV}$ peak of actinium-228 $\left({ }^{228} \mathrm{Ac}\right)$.

The results are

- uranium $-238=45.4 \mathrm{~Bq} / \mathrm{kg}$

- uranium-235 $=10.1 \mathrm{~Bq} / \mathrm{kg}$

norium $-232=18.9 \mathrm{~Bq} / \mathrm{kg}$.
Table 2 shows the values of uranium-238, radium-226 $\left({ }^{226} \mathrm{Ra}\right)$ and thorium-232 present in PG in different regions in the world. The activities of thorium-232 and uranium-238 (15 and $47 \mathrm{~Bq} / \mathrm{kg}$, respectively) are lower than those found in different Tunisian phosphate ores (19.5 for thorium and $17.1 \mathrm{~Bq} / \mathrm{kg}$ for uranium), and thus, they do not present any risk for the environment. The table shows that the activities of radium-226 found in Tunisian PG $(215 \mathrm{~Bq} / \mathrm{kg}$ as an average) remain lower than those found for the majority of PGs. Furthermore, radium-226, which is the principal environmental concern, remains stored in the PG.

The radioactivity values of thorium-232, uranium-235 and uranium238 of raw PG are less than the limit values required by the council directive of the EU (2013/59/Euratom) ${ }^{17}$ of 5 December 2013 laying down basic safety standards for protection against the dangers arising from exposure to ionizing radiation (Table 3).

\subsubsection{Characteristics of aggregates}

The paving blocks' standard formulation consists of $46 \%$ crushed stone aggregate $(0 / 4)$ and $34 \%$ fine aggregate (sand). The gradations of coarse and fine aggregates are shown in Figures 7 and 8 , respectively.

\subsubsection{Characteristics of cement}

Portland cement CEM I 42.5 from a Gabès cement plant (Tunisia) is used. Bogue's composition, density and Blaine fineness are provided in Table 4.

\subsection{Methods}

The experimental program was performed in two steps.

- At the laboratory. Prismatic specimens $(4 \times 4 \times 16 \mathrm{~cm})$ were prepared by partially substituting sand with $\mathrm{PG}$ at ratios of 0 , 10, 20, 30, 40, 50 and $60 \%$ (Table 5). The objective was to identify an optimal PG-substitution rate.

Table 3. Activity concentration values $(\mathrm{Bq} / \mathrm{kg})$

\begin{tabular}{lccc|} 
& Uranium-238 & Uranium-235 & Thorium-232 \\
\hline Raw PG & 45.4 & 10.1 & 18.9 \\
Limit values required & $1 \times 10^{4}$ & $1 \times 10^{4}$ & $1 \times 10^{3}$ \\
by council directive & & & \\
of the EU & & & \\
$(\text { (2013/59/Euratom) })^{17}$ & & & \\
\hline
\end{tabular}

Table 2. PG radioactivity throughout the world $(\mathrm{Bq} / \mathrm{kg})$

\begin{tabular}{|c|c|c|c|c|c|}
\hline Origin of PG & Origin of phosphate & Uranium-238 & Radium-226 & Thorium-232 & Reference \\
\hline Tunisia & Tunisia & $47(35-66)$ & 215 (209-223) & $15(8-20)$ & Reguigui et al. ${ }^{10}$ \\
\hline Tunisia & Tunisia & - & 350 & - & Mahjoubi et al. ${ }^{11}$ \\
\hline Greece & Togo & - & 261 & - & Papastefanou ${ }^{12}$ \\
\hline Australia & & 510 & $451-500$ & 10 & Rutherford $^{13}$ \\
\hline Florida, USA & Central Florida & $130(93-190)$ & $1120(836-1670)$ & 3.7 & Rutherford $^{13}$ \\
\hline Morocco & Morocco & & 1420 & & Azouazi et al. ${ }^{14}$ \\
\hline Egypt & Egypt & 134 & 411 & 19 & Bigu et al. ${ }^{15}$ \\
\hline Spain & & & 727 (470-1536) & & Aguado et al. ${ }^{16}$ \\
\hline
\end{tabular}




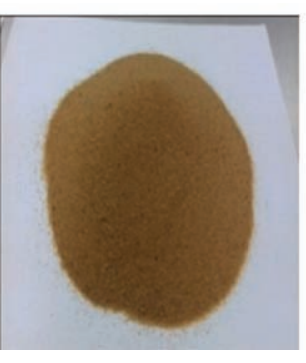

Sand

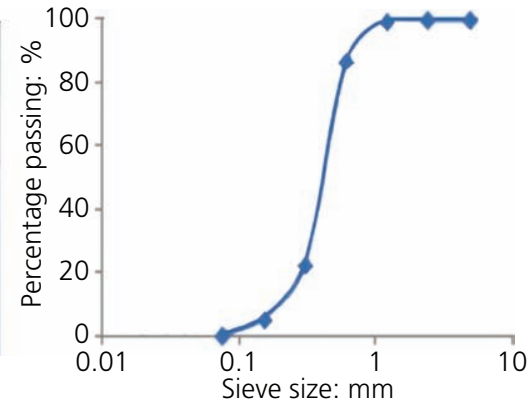

Figure 7. PSD curve of fine sand
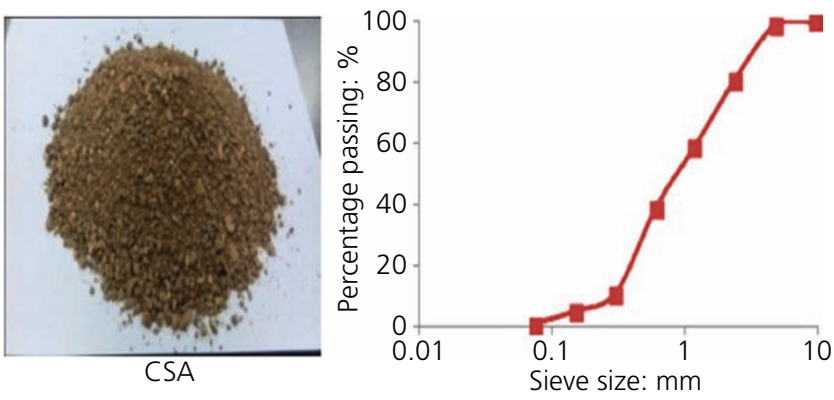

Figure 8. PSD curve of crushed stone aggregate (CSA)

- At the factory. The optimal PG-substitution rate was used to prepare the paving block samples needed to fulfill the testing program.

The industrial scale involves the preparation of paving blocks by substituting sand with $20 \%$ PG. The used PG in the experimental program was previously dried before being added to the mixes. All the physical and mechanical tests were conducted on three samples, and the figures represent the average of the trials.

Table 4. Bogue's composition (mass percentage), density and fineness of cement

\begin{tabular}{|cccccc|}
\hline $\mathrm{C}_{3} \mathrm{~S}: \%$ & $\mathrm{C}_{2} \mathrm{~S}: \%$ & $\mathrm{C}_{3} \mathrm{~A}: \%$ & $\mathrm{C}_{4} \mathrm{AF}: \%$ & Density & $\begin{array}{c}\text { Blaine } \\
\text { fineness: } \mathrm{m}^{2} / \mathrm{kg}\end{array}$ \\
\hline 71.18 & 5.95 & 6.93 & 8.98 & 3.02 & 318 \\
\hline
\end{tabular}

$\mathrm{C}_{2} \mathrm{~S}$, dicalcium silicate (belite); $\mathrm{C}_{3} \mathrm{~A}$, tricalcium aluminate; $\mathrm{C}_{3} \mathrm{~S}$, tricalcium silicate (alite); $C_{4} A F$, tetracalcium aluminoferrite

Table 5. Mix proportions of concrete mixtures $\left(\mathrm{kg} / \mathrm{m}^{3}\right)$

\begin{tabular}{lcccc} 
Mix & $\begin{array}{c}\text { Cement } \\
\text { (CEM 42.5): } \mathbf{k g} / \mathbf{m}^{3}\end{array}$ & $\begin{array}{c}\text { CSA (0/4): } \\
\mathbf{k g} / \mathbf{m}^{\mathbf{3}}\end{array}$ & $\begin{array}{c}\text { Sand: } \\
\mathbf{k g} / \mathbf{m}^{\mathbf{3}}\end{array}$ & $\begin{array}{c}\text { PG: } \\
\mathbf{k g} / \mathbf{m}^{\mathbf{3}}\end{array}$ \\
\hline M0 & 310 & 1102 & 818 & 0 \\
M10 & 310 & 1102 & 736.2 & 81.80 \\
M20 & 310 & 1102 & 654.4 & 163.60 \\
M30 & 310 & 1102 & 572.6 & 245.40 \\
M40 & 310 & 1102 & 490.8 & 327.20 \\
M50 & 310 & 1102 & 409.0 & 409.00 \\
M60 & 310 & 1102 & 327.2 & 490.80 \\
\hline
\end{tabular}

\subsubsection{Laboratory specimens}

\subsubsection{SAMPLE PREPARATION AND CURING}

The mixing, casting and curing of the specimens were done in accordance with the European standard NF EN 196-1 ${ }^{18}$ for prismatic specimens (Figure 9).

- Mixing. Water was poured into the container and introduced into the cement. Immediately, the mixer was operated at a low speed, and after $30 \mathrm{~s}$, all the sand and PG were introduced regularly during the next $30 \mathrm{~s}$. Then, the mixer was set to its highest speed to continue mixing for $30 \mathrm{~s}$. After that, the mixer was stopped for $1 \mathrm{~min}$ and $15 \mathrm{~s}$. During the first $15 \mathrm{~s}$, all the mortar adhering to the walls and the bottom of the container was removed with a squeegee rubber by pushing it toward the middle of the mixer; then, mixing was resumed at a high speed for $60 \mathrm{~s}$.

- Casting. The casting of specimens was carried out immediately after preparation of the mortar using a shock table and standard molds $(4 \times 4 \times 16 \mathrm{~cm})$.

- Curing. The curing of specimens was performed by placing a glass or steel plate on the perimeter of the mold and placing the mold in a humid room for $24 \mathrm{~h}$. Then, the test pieces were carefully unmolded marked and finally stored in water at $20^{\circ} \mathrm{C}$.

\subsubsection{PHYSICAL AND MECHANICAL TESTS}

After appropriate curing, the specimens were tested.

- Physical tests. Density, water absorption and apparent porosity were determined in accordance to the British standard BS EN 1338:2003. ${ }^{19}$

- Mechanical tests. The compressive and flexural strength test were carried out according to the European standard NF EN $196-1 .^{18}$

To determine the flexural strength, a concentrated load is applied at midspan. The failure load was recorded, and the flexural strength $R_{\mathrm{f}}$ was calculated using the equation

1. $R_{\mathrm{f}}=\frac{1.5 \times F_{\mathrm{f}} \times l}{b^{3}}$

where $R_{\mathrm{f}}$ is the flexural strength $\left(\mathrm{N} / \mathrm{mm}^{2}\right) ; F_{\mathrm{f}}$ is the breaking load at the middle of the prism $(\mathrm{N}) ; l$ is the distance between the supports (mm); and $b=40 \mathrm{~mm}$.

The half-prisms resulting from the bending test were used again for compressive strength test. The compressive strength was calculated using the equation

2. $R_{\mathrm{c}}=\frac{F_{\mathrm{c}}}{1600}$ 


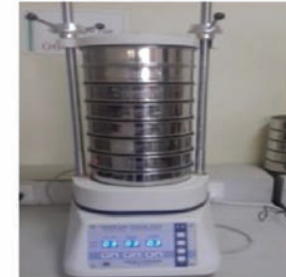

Laboratory sieve

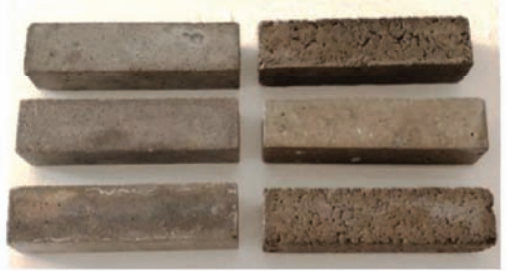

Prismatic specimens $(4 \times 4 \times 16)$

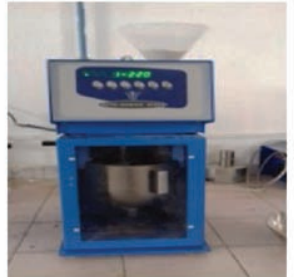

Mixer

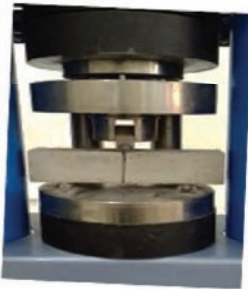

Flexion test

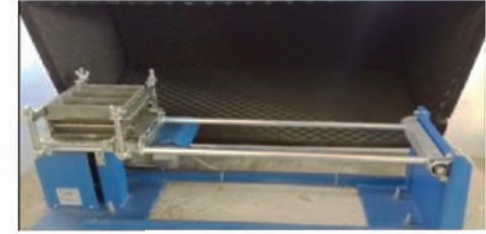

Shock table

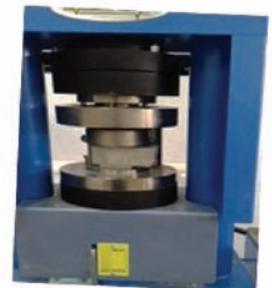

Compression test

Figure 9. Laboratory blocks

where $R_{\mathrm{c}}$ is the compressive strength $\left(\mathrm{N} / \mathrm{mm}^{2}\right) ; F_{\mathrm{c}}$ is the breaking load $(\mathrm{N})$; and $1600=40 \times 40 \mathrm{~mm}$.

\subsubsection{Industrial paving blocks}

Once all laboratory testing was performed, the retained mix design was used to manufacture paving blocks under factorycontrolled conditions at STIB-Tunisia (a precast concrete factory

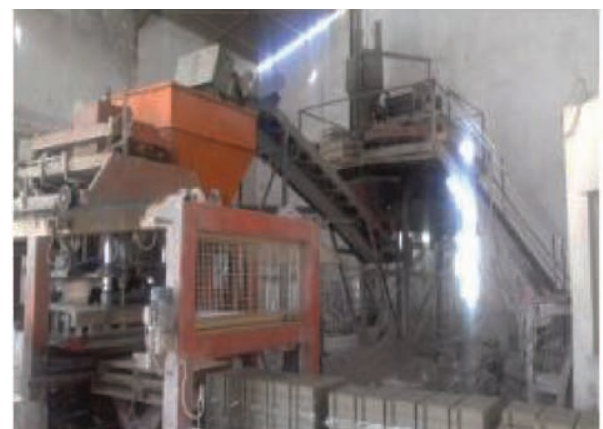

Transport of materials

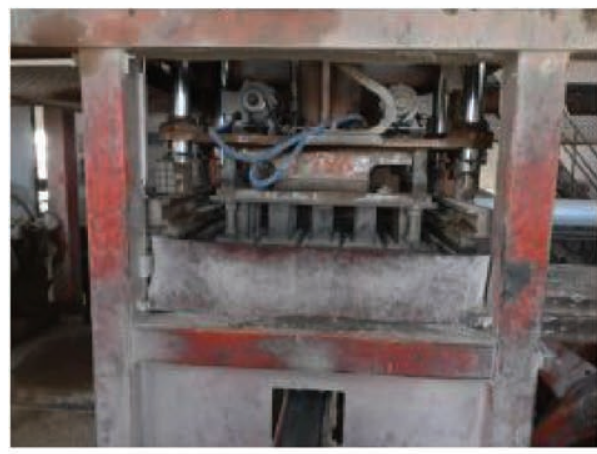

Compacting machine located in Medenine City in Southern Tunisia and specializing in paving block manufacturing).

The process of manufacturing the PG paving blocks (FPGPB) is shown in Figure 10: cement, fine and coarse aggregates and PG were mixed for $1 \mathrm{~min}$ in the mixer; afterwards, water was added and mixed for another $2 \mathrm{~min}$. At the end of the mixing cycle, the exact moisture

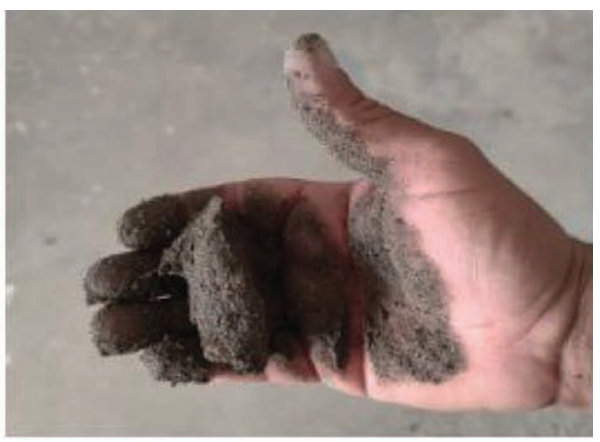

Mortar consistency

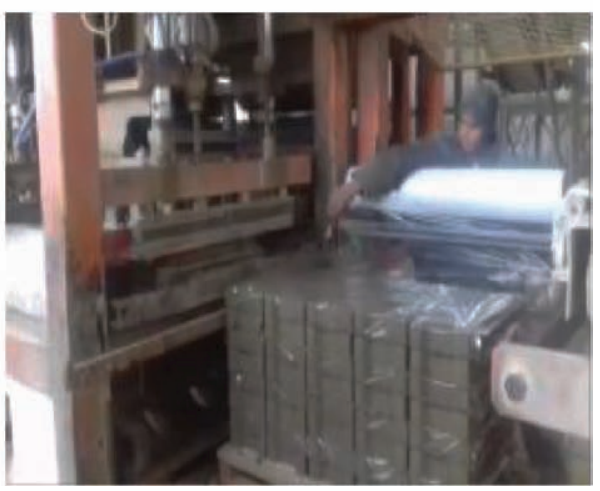

Freshly formed paving blocks

Figure 10. Steps of industrial manufacturing of factory-PG-amended paving blocks containing $20 \%$ PG 
level was controlled in order to avoid the mixture being too fluid or too firm. Indeed, the fresh mortar should take the form of a dry rod by squeezing it firmly between the palm of the hand and fingers. ${ }^{20}$

\section{Results and discussion}

\subsection{Test results of laboratory blocks \\ 3.1.1 Physical properties}

\subsubsection{WATER ABSORPTION AND POROSITY}

The results for the water absorption test are provided in Figure 11. The British standard (BS EN 1338: 2003) ${ }^{19}$ requires a maximum water absorption coefficient of $6 \%$ for paving blocks at the industrial scale. The specimens prepared with a PG-replacement rate of less than $20 \%$ meet the above requirement.

As shown in Figure 11, water absorption coefficient of the concrete blocks increases gradually below 20\% PG-replacement rate. Then, for greater PG-replacement rates, a more rapid increase is observed, and the $6 \%$ limit is exceeded. In fact, at higher PG-replacement rates, the water demand for wetting filler particles increases as a result of PG higher specific area, which leads to an increase in porosity and consequently an increase in water absorption (Figure 12).

\subsubsection{DRY AND WET DENSITIES}

The dry and wet densities of the hardened concrete mixtures are shown in Figure 13. The partial sand substitution with PG causes

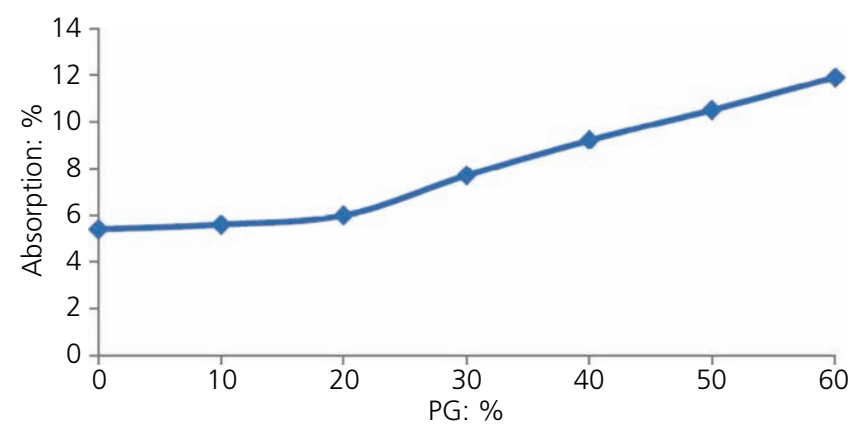

Figure 11. Water absorption of concrete mixtures

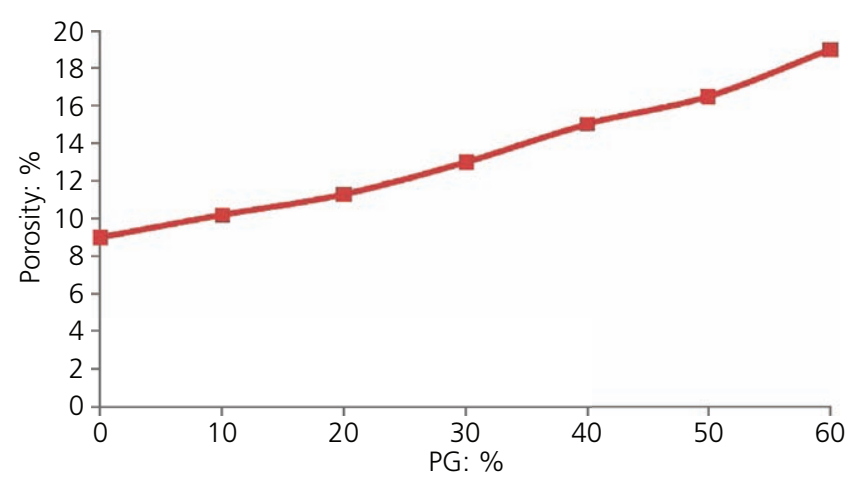

Figure 12. Porosity of concrete mixtures

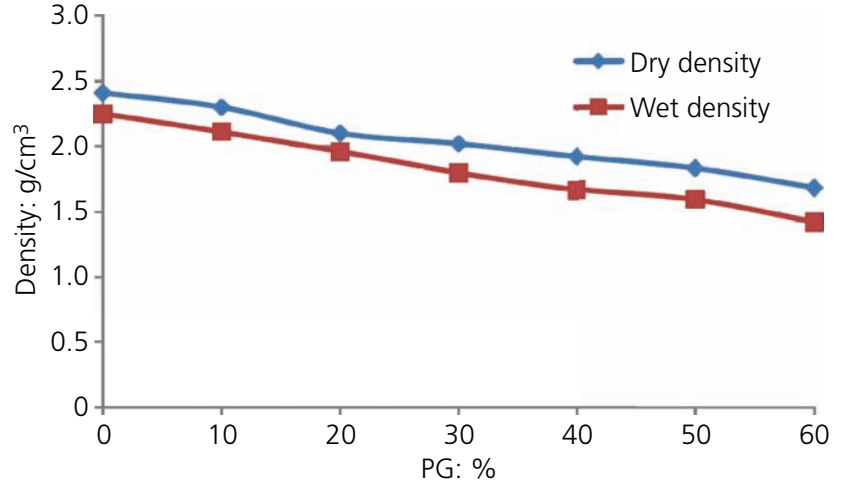

Figure 13. Dry and wet densities of concrete mixtures

a decrease in dry and wet densities. These results indicate that there is a slight decrease in the density of concrete samples with PG-substitution rates increasing up to $20 \%$. The filling of intergranular voids with the fine PG particles improves the particle packing, thus resulting in densification of the hardened concrete, ${ }^{21}$ whereas using more than $20 \%$ PG leads to a decrease in the density due to the lower PG specific gravity.

\subsubsection{Mechanical properties}

All mechanical tests, including compressive and flexural strength tests, were performed at standard curing times (7, 28 and 90 days). The results performed represent the average of three samples for the flexural strength test, and six samples for compressive strength test.

\subsubsection{COMPRESSIVE STRENGTH}

The effect of using PG in substitution of sand on the compressive strength is shown in Figure 14. For 20\% PG-substitution rate, acceptable compressive strengths of 20,25 and $27 \mathrm{MPa}$ were measured at 7, 28 and 90 days, respectively. Beyond this substitution rate, the compressive strength has considerably decreased by $28 \%$ for $30 \%$ PG-substitution rate and by $68 \%$ for $30 \%$ PG-substitution rate at a sample age of 28 days.

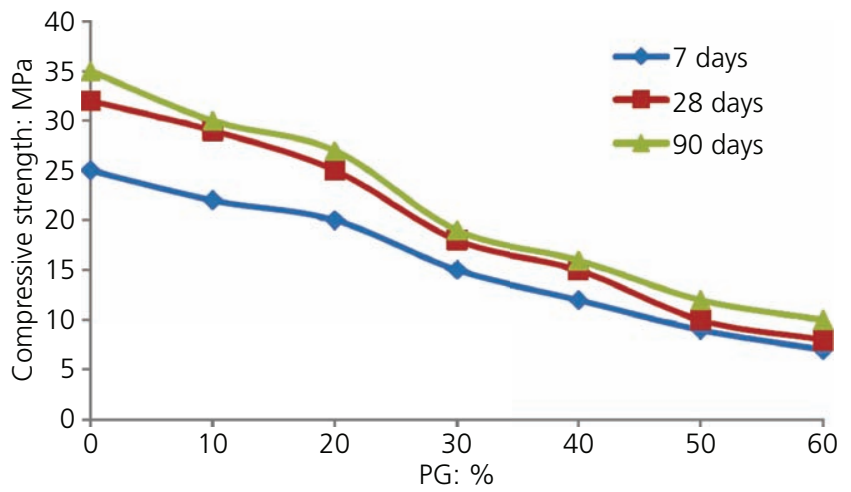

Figure 14. Compressive strength of concrete mixtures 


\subsubsection{FLEXURAL STRENGTH}

The flexural strength of concrete paving blocks was measured for different PG-substitution rates (Figure 15). The lowest value of the flexural strength measured for sample M60 was $1.8 \mathrm{MPa}$ at 7 days, whereas the highest value measured for sample M10 was $5.39 \mathrm{MPa}$ at the same age. Therefore, compared with reference mix M0, the addition of PG at different rates results in a decrease in the flexural strength. As observed in the same figure, the flexural strength decreases considerably with the addition of $\mathrm{PG}$ at rates greater than $20 \%$. For higher PG-substitution rates, the decrease in flexural strength follows the same trend as that for compressive strength.

The measured decrease in the compressive and flexural strengths of samples with sand replacement by PG is mostly due to the weak hardness of PG crystals compared with that of silica grains. This decrease can be also attributed to the combined effect of a lower reacting cement content, a lower cementing value of the hydrated gypsum and possible retardation of cement reaction due to the presence of anhydrite and impurities (mostly from phosphate).

\subsection{Test results of industrial paving blocks}

\subsubsection{Visual and physical characteristics}

The factory-produced PG paving blocks (FPGPB) are gray in color with regular smooth surfaces (Figure 16), porous surfaces and a lower density compared with those of reference blocks. The unit weight densities of the reference factory-made blocks (FPGPB-0) and laboratory-made ones (LPGPB-0) are provided in Figure 17. A $10.6 \%$ unit weight gain was calculated for FPGPB-20 compared with LPGPB-20. Obviously, the gain is due to the efficient compaction and vibration methods used in the plant. The result is confirmed in the study of the effects of the compaction method and rubber content on the properties of concrete paving blocks, ${ }^{22}$ with an improvement in density of $10.7 \%$ for mixtures with rubber replacement for paving blocks produced in the laboratory and under plant conditions.

\subsubsection{Water absorption}

The FPGPB water absorption test results are provided in Table 6 . The water absorption coefficient of FPGPB with 20\% PG (FPGPB-20) is within allowable limits (5.7\%, lower than 6\%).

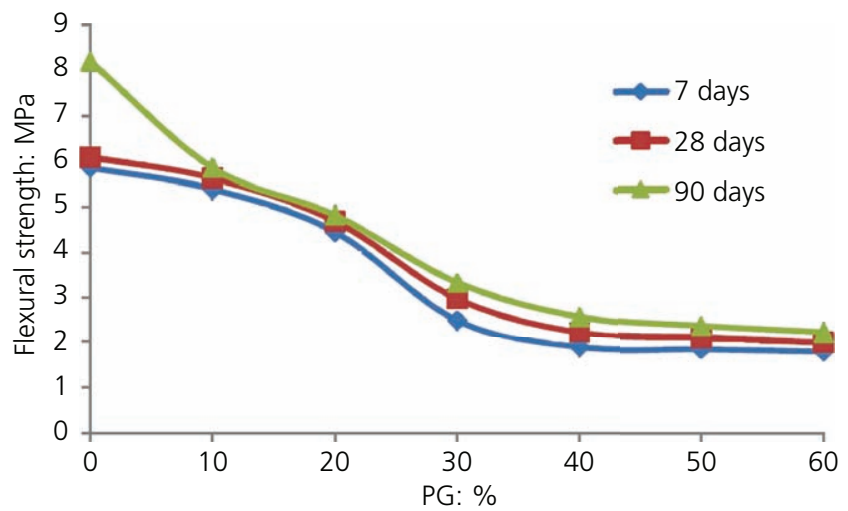

Figure 15. Flexural strength of concrete mixtures

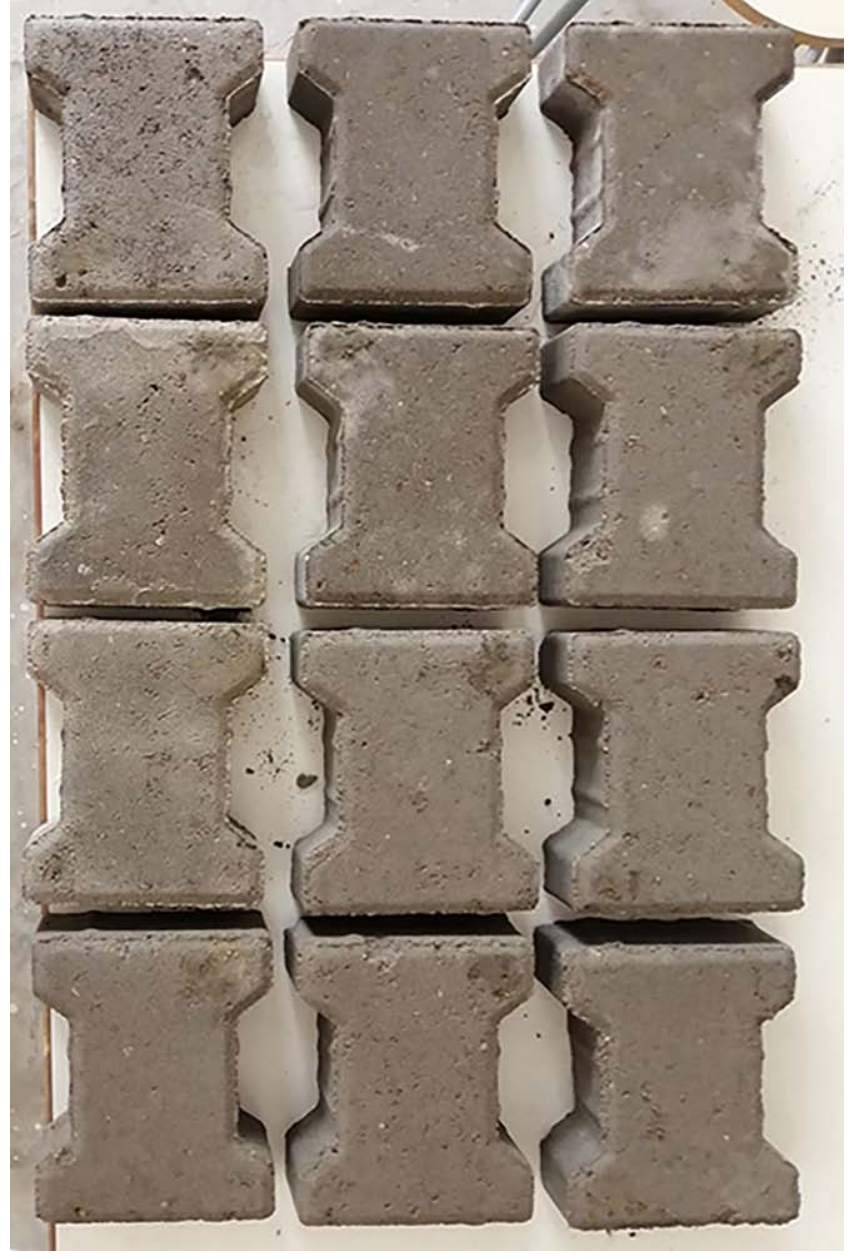

Figure 16. Visual characteristics of FPGPB

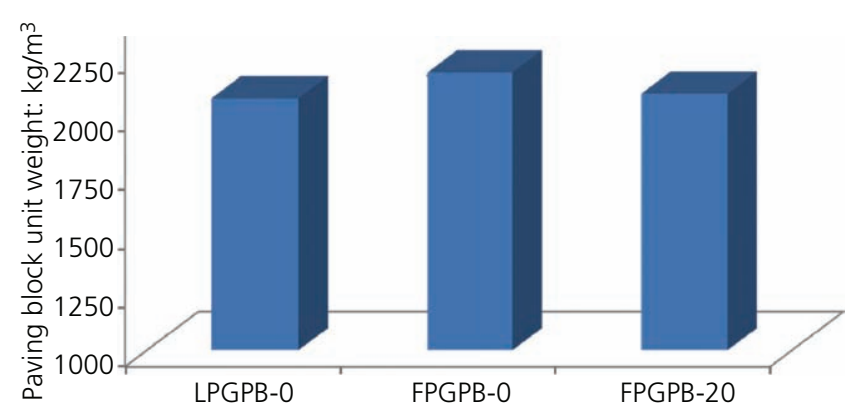

Figure 17. Unit weight densities of LPGPB-0, FPGPB-0 and FPGPB-20

Table 6. Absorption rate results of factory-made paving blocks (FPGPB-0 and FPGPB-20) 
However, it is greater than the water absorption coefficient of the reference paving blocks (FPGPB-0) because PG requires a lot of water. In comparison with lab samples, lower values were measured (5.4 and 6\% for LPGPB-0 and LPGPB-20, respectively) due to better granular compaction enhanced by $\mathrm{PG}$ granularity.

According to published surveys, similar green products may have absorption coefficients largely exceeding standard limits. For example, green interlocking pavement (GIP) blocks were developed with coconut shell ash. The absorption coefficient is $12.97 \%{ }^{23}$

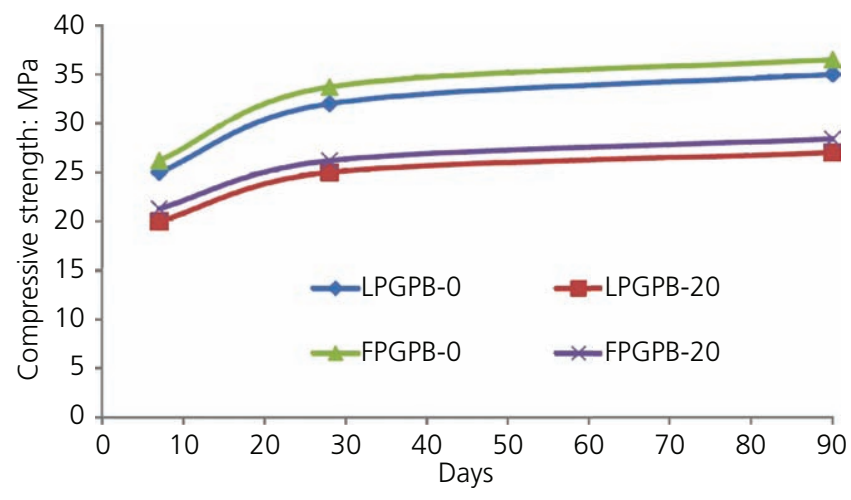

Figure 18. Comparison between laboratory and industrial results for compressive strength

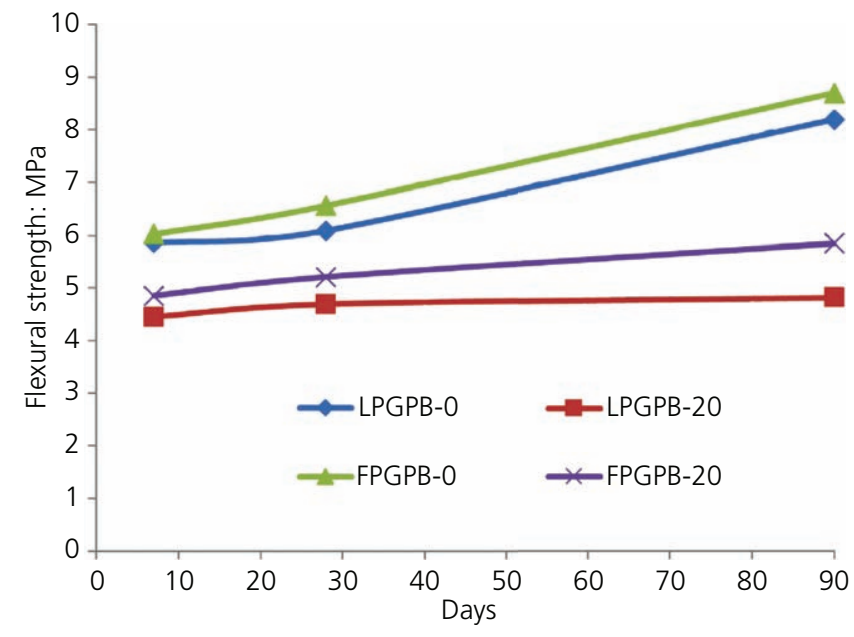

Figure 19. Comparison between laboratory and industrial results for flexural strength

\subsubsection{Compressive and flexural strengths}

The compressive and flexural strengths of FPGPB were determined at 7, 28 and 90 days. The average compressive strengths for factory and laboratory paving blocks for zero and $20 \%$ PG-substitution rates are provided in Figure 18. As expected, the compressive and the flexural strengths increase with respect to the curing periods of the sample. Indeed, with reference to 7-daycured samples, the compressive strength improves by $26 \%$ at 28 days and by $36 \%$ at 90 days and flexural strength improves by $6 \%$ at 28 days and $10 \%$ at 90 days. The mechanical strengths of factory blocks are higher than those of the laboratory ones due to the efficiency of the manufacturing process (Figures 18 and 19).

As expected, a loss of strength compared with the reference mix was observed: $24 \%$ at 7 days and $27 \%$ at 28 days. Nevertheless, a $20.7 \mathrm{MPa}$ compressive strength at 7 days is still acceptable for intended use. An explanation of the strength loss is the PG tubular crystalline form being weaker than sand's granular form which allows more packing ability and therefore more strength.

PG-based paving blocks have 28-day compressive and flexural strength results of 28.4 and $5.85 \mathrm{MPa}$, respectively. The former results are in good agreement with published work on similar products. For instance, GIP blocks ${ }^{23}$ have a compressive strength of $25.868 \mathrm{MPa}$, rubberized concrete blocks $(\mathrm{RCBs})^{24}$ have a compressive strength of $25.2 \mathrm{MPa}$; RCBs developed a flexural strength of $3.3 \mathrm{MPa}^{22}$

\subsubsection{Leaching test}

In order to determine the concentrations of heavy metals in factory paving blocks, a leaching test was carried out according to the British standard BS EN 12457-4. ${ }^{25}$ The results are compared with those of raw PG (Table 7). The factory paving blocks were crushed and sieved below a $4 \mathrm{~mm}$ sieve opening size in order to be leached using water. It is observed that leached metal concentrations of factory paving blocks are lower than raw PG leaching test results. Indeed, concentrations of zinc $(\mathrm{Zn})$, nickel (Ni) and copper $(\mathrm{Cu})$ are lower compared with those of leached metals of raw PG. For example, the zinc concentration decreases from 3.055 to $0.041 \mathrm{mg} / \mathrm{l}$, that of copper from 0.139 to $0.041 \mathrm{mg} / \mathrm{l}$ and that of nickel from 0.203 to $0.013 \mathrm{mg} / \mathrm{l}$ for raw $\mathrm{PG}$ and manufactured paving blocks, respectively. A reasonable explanation would be the trapping of PG in the cement mortar matrix. A similar technique, called the stabilization method used by Hale et al., ${ }^{26}$ consists of using cement as a binder to stabilize partially some metals such as chromium $(\mathrm{Cr})$, lead $(\mathrm{Pb})$, cadmium (Cd) and zinc.

Table 7. Trace element content (mg/l)

\begin{tabular}{lcccccc} 
& Cadmium & Copper & Lead & Nickel & Zinc & Chromium \\
\hline Concentration in PG: $\mathrm{mg} / \mathrm{l}$ & 0.062 & 0.139 & 0.472 & 0.203 & 3.055 & 0.056 \\
Concentration in factory paving blocks M20: $\mathrm{mg} / \mathrm{l}$ & 0.014 & 0.041 & 0.350 & 0.013 & 0.041 & 0.035 \\
Leaching limit values set by the council decisions of the EU (2003/33/EC): mg/l & 0.300 & 30 & 3 & 3 & 15 & 2.500
\end{tabular}


Leaching test results are much lower than the leaching limit values set by the council decisions of the EU on 19 December $2002(2003 / 33 / \mathrm{EC}),{ }^{27}$ and therefore, the paving block does not constitute any significant environmental impact (Table 7).

\section{Conclusions}

To contribute to attenuation of the environmental degradation of marine ecosystems due to direct discharge into the sea of PG waste from a Gabès phosphate plant, the present investigation shows high potential for the reuse of PG waste in the paving block industry. Preliminary lab tests were conducted to determine the optimal PG-substitution rate. In comparison with a control mix commonly used at the industrial scale, a mix with $20 \%$ PG waste substituting fine sand is proven to meet physical, mechanical and health requirements. Samples were prepared in the factory, and a comprehensive experimental investigation was conducted. Relevant results from this investigation are as follows.

- The density of PG-based paving blocks is lower than that of similar products (made using the reference mix) available on the market $(4.13 \%)$.

- The water absorption rate of PG-based paving blocks (5.7\%) satisfies the value required $(6 \%)$ by the working standard BS EN 1338. ${ }^{19}$

- FPGPB mechanical strengths increase with respect to curing periods. With reference to the 7-day curing period

- the compressive strength improves by $26 \%$ at 28 days and by $36 \%$ at 90 days

- the flexural strength improves by $6 \%$ at 28 days and $10 \%$ at 90 days.

- Leaching test results show low concentrations of heavy metals in FPGPB samples below recommendations of the council decision of the EU on 19 December 2002 (2003/33/EC). ${ }^{27}$

- Leached metal concentrations in samples are less than those measured in the raw PG.

- The measured radioactivity of raw PG radionuclides (thorium232, uranium-235 and uranium-238) is found to be lower than the limit values fixed by the council directive of the EU (2013/59/Euratom). ${ }^{17}$

For all the aforementioned results, the innovative approach (reuse of PG waste in paving blocks) provides environment managers and decision makers an alternate solution with less human health risk. Nevertheless, future expansion of the present work is needed and would address in more depth the durability features of PG-based paving blocks as a promising eco-friendly and green product.

\section{Acknowledgements}

The authors would like to acknowledge the Research Center of Borj Cedria - Tunisia for all facilities offered. Thanks are also addressed to the STIB Plant of Medenine for their support in manufacturing PG-based paving blocks.

\section{REFERENCES}

1. Saadaoui E, Ghazel N, Ben Romdhane C and Massoudi N (2017) Phosphogypsum: potential uses and problems - a review. International Journal of Environmental Studies 74(4): 558-567.

2. Macías F, Pérez-López R, Cánovas $C R$, Carrero $S$ and Cruz-Hernandez $P$ (2017) Environmental assessment and management of phosphogypsum according to European and United States of America regulations. Procedia Earth and Planetary Science 17: 666-669.

3. Zmemla R, Sdiri A, Naifar I, Benjdidia M and Elleuch B (2020) Tunisian phosphogypsum tailings: assessment of leaching behavior for an integrated management approach. Environmental Engineering Research 25(3): 345-355.

4. Campos MP, Costa LJP, Nisti MB and Mazzilli BP (2017) Phosphogypsum recycling in the building materials industry: assessment of the radon exhalation rate. Journal of Environmental Radioactivity 172: 232-236.

5. Carmeis Filho ACA, Penn CJ, Crusciol CAC and Calonego JC (2017) Lime and phosphogypsum impacts on soil organic matter pools in a tropical Oxisol under long-term no-till conditions. Agriculture, Ecosystems \& Environment 241: 11-23.

6. Islam GMS, Chowdhury FH, Raihan MT, Amit SKS and Islam MR (2017) Effect of phosphogypsum on the properties of Portland cement. Procedia Engineering 171: 744-751.

7. Amrani M, Taha Y, Kchikach A, Benzaazoua M and Hakkou R (2020) Phosphogypsum recycling: new horizons for a more sustainable road material application. Journal of Building Engineering 30: 101267.

8. Rashad AM (2017) Phosphogypsum as a construction material. Journal of Cleaner Production 166: 732-743.

9. ASTM (1993) D 3282: Standard practice for classification of soils and soil - aggregate mixtures for highway construction purposes. ASTM International, West Conshohocken, PA, USA.

10. Reguigui N, Sfar Felfoul H, Ben Ouezdou M and Clastres P (2005) Radionuclide levels and temporal variation in phosphogypsum. Journal of Radioanalytical and Nuclear Chemistry 264(3): 719-722.

11. Mahjoubi H, Charfi AH, Labidi S, Chahed N and Mtimet S (2000) Estimation des expositions associées à la présence du radon 222 dans les usines de traitement de phosphates et leurs environnements en Tunisie. Radioprotection 35(2): 201-215 (in French).

12. Papastefanou C (2001) Radiological impact from atmospheric releases of ${ }^{238} \mathrm{U}$ and ${ }^{226} \mathrm{Ra}$ from phosphate rock processing plants. Journal of Environmental Radioactivity 54(1): 75-83.

13. Rutherford PM, Dudas MJ and Samek RA (1994) Environmental impacts of phosphogypsum. Science of the Total Environment 149(1-2): 1-38.

14. Azouazi M, Ouahidi Y, Fakhi S et al. (2001) Natural radioactivity in phosphates, phosphogypsum and natural waters in Morocco. Journal of Environmental Radioactivity 54(2): 231-242.

15. Bigu J, Hussein MI and Hussein AZ (2000) Radioactivity measurements in Egyptian phosphate mines and their significance in the occupational exposure of mine workers. Journal of Environmental Radioactivity 47(3): 229-243.

16. Aguado JL, Bolivar JP and García-Tenorio R (2008) ${ }^{226} \mathrm{Ra}$ and ${ }^{228} \mathrm{Ra}$ determination in environmental samples by alpha-particle spectrometry. Journal of Radioanalytical and Nuclear Chemistry 49(S1): 439-444, https://doi.org/10.1007/s10582-999-0059-7.

17. EU (European Union) (2013) Council Directive 2013/59/Euratom of 5 December 2013 laying down basic safety standards for protection against the dangers arising from exposure to ionising radiation, and repealing Directives 89/618/Euratom, 90/641/Euratom, 96/29/Euratom, 97/43/ Euratom and 2003/122/Euratom. Official Journal of the European Union L13/1.

18. Afnor (Association Française de Normalisation) (2006) NF EN 196-1. Méthode d'essais des ciments. Partie 1: détermination des résistances mécaniques. Afnor, Paris, France (in French).

19. BSI (2003) BS EN 1338:2003: Concrete paving blocks. Requirements and test methods. BSI, London, UK. 
20. Soutsos MN, Tang K and Millard SG (2011) Use of recycled demolition aggregate in precast products, phase II: concrete paving blocks. Construction and Building Materials 25(7): 3131-3143.

21. Li B, Wang J and Zhou M (2009) Effect of limestone fines content in manufactured sand on durability of low- and high-strength concretes. Construction and Building Materials 23(8): 2846-2850.

22. Ling TC (2012) Effects of compaction method and rubber content on the properties of concrete paving blocks. Construction and Building Materials 28(1): 164-175.

23. Kassim U and Rohim OM (2017) Sustainable green interlocking pavement block. Journal of Advanced Research in Applied Sciences and Engineering Technology 8(1): 1-7.

24. Murugan RB, Natarajan C and Chen SE (2016) Material development for a sustainable precast concrete block pavement.
Journal of Traffic and Transportation Engineering (English Edition) 3(5): 483-491.

25. BSI (2002) BS EN 12457-4:2002: Characterisation of waste. Leaching. Compliance test for leaching of granular waste materials and sludges. One stage batch test at a liquid to solid ratio of $101 / \mathrm{kg}$ for materials with particle size below $10 \mathrm{~mm}$ (without or with size reduction). BSI, London, UK.

26. Hale B, Evans L and Lambert R (2012) Effects of cement or lime on $\mathrm{Cd}, \mathrm{Co}, \mathrm{Cu}, \mathrm{Ni}, \mathrm{Pb}, \mathrm{Sb}$ and $\mathrm{Zn}$ mobility in field-contaminated and aged soils. Journal of Hazardous Materials 199-200: 119-127.

27. EU (2002) Council Decision of 19 December 2002 establishing criteria and procedures for the acceptance of waste at landfills pursuant to Article 16 of and Annex II to Directive 1999/31/EC (2003/33/EC). Official Journal of the European Communities L11/27.

\section{How can you contribute?}

To discuss this paper, please submit up to 500 words to the journal office at journals@ice.org.uk.Your contribution will be forwarded to the author(s) for a reply and, if considered appropriate by the editor-in-chief, it will be published as a discussion in a future issue of the journal.

ICE Science journals rely entirely on contributions from the field of materials science and engineering. Information about how to submit your paper online is available at www.icevirtuallibrary.com/page/authors, where you will also find detailed author guidelines. 